\title{
Bacteria and Foraminifera: key players in a short-term deep-sea benthic response to phytodetritus
}

\author{
Leon Moodley ${ }^{1, *}$, Jack J. Middelburg ${ }^{1}$, Hendricus T. S. Boschker ${ }^{1}$, \\ Gerard C. A. Duineveld ${ }^{2}$, Roel Pel ${ }^{3}$, Peter M. J. Herman ${ }^{1}$, Carlo H. R. Heip ${ }^{1}$ \\ ${ }^{1}$ Netherlands Institute of Ecology (NIOO-CEMO), PO Box 140, 4400 AC Yerseke, The Netherlands \\ ${ }^{2}$ Netherlands Institute for Sea Research (NIOZ), PO Box 59, 1790 AB Den Burg, Texel, The Netherlands \\ ${ }^{3}$ Netherlands Institute of Ecology (NIOO-CL), PO Box 1299, 3600 BG Maarssen, The Netherlands
}

\begin{abstract}
The deep-sea floor has long been considered a 'food desert' but recent observations suggest that episodic inputs of relatively fresh organic matter (phytodetritus) occur and that benthic processing of this material may be rapid. Although the responses of the total community in terms of oxygen consumption and of some individual benthic groups have been identified, the quantitative role of the different groups in the short-term response remains largely unknown. We examined the short-term response in major benthic compartments in an in situ experiment in the NE Atlantic (2170 m water depth) using ${ }^{13} \mathrm{C}$-enriched diatoms as a tracer of labile carbon. Within $35 \mathrm{~h}, 6 \mathrm{mg} \mathrm{C} \mathrm{m}{ }^{-2}$ was processed by the benthos, with the majority of the processed carbon recorded as respiration $(45 \%)$. Among the fauna retained on a $300 \mu \mathrm{m}$ sieve, Foraminifera were rapid consumers which, together with Bacteria, accounted for $50 \%$ of the processing. Therefore, although Bacteria dominate long-term carbon mineralization (as suggested by their general dominance in the benthic biomass), some faunal components, in this case Foraminifera, may play a central role in the rapid initial processing of fresh organic carbon in deep-sea sediments.
\end{abstract}

KEY WORDS: Deep-sea $\cdot$ Benthic-pelagic coupling $\cdot{ }^{13} \mathrm{C}$ labelling $\cdot$ Tracer $\cdot$ Respiration $\cdot$ Bacteria $\cdot$ PLFA $\cdot$ Foraminifera $\cdot$ Benthos

Resale or republication not permitted without written consent of the publisher

\section{INTRODUCTION}

The benthic processing of organic matter (OM) determines the amount and composition of organic carbon buried in marine sediments. A significant part of the carbon input to deep-sea sediments occurs in the form of short-lived deposition events of relatively fresh organic matter (Billett et al. 1983, Thiel et al. 1989) and a dynamic pelagic-benthic coupling may exist (Smith \& Baldwin 1984, Graf 1989, Gooday \& Turley 1990, Drazen et al. 1998). However, a benthic response is not always evident (Sayles et al. 1994, Ahrens et al. 1997, Pfannkuche et al. 1999, Smith \&

*E-mail: moodley@cemo.nioo.knaw.nl
Kaufmann 1999) and may depend not only on the quality and quantity of the settling material (Sayles et al. 1994, Soetaert et al. 1996) but also on the timing of the observations (Pfannkuche et al. 1999). The benthic response in terms of sediment community oxygen consumption may be rapid and rather brief (Graf 1992) and therefore easily missed in field observations (Smith \& Kaufmann 1999, Witte \& Pfannkuche 2000). In terms of faunal response, the standing stock or biomass may not be a good indicator of direct processing of OM, as it reflects both the net outcome of individual OM uptake pathways and biological interactions (Pfannkuche et al. 1999). The use of tracers, however, allows a direct examination of deep-sea benthic responses. Pioneering studies revealed rapid assimilation of organic carbon by an undifferentiated micro- 
meiofaunal community (Cahet \& Sibuet 1986, Cahet et al. 1990) and a rapid uptake of fresh phytodetritus by some individual benthic taxa (Blair et al. 1996, Levin et al. 1997, 1999). Similarly, the response of some individual groups has been examined in enrichment experiments with deep-sea sediments (e.g. Turley \& Lochte 1990, Altenbach 1992, Linke 1992, Linke et al. 1995, Boetius \& Lochte 1996, Relexans et al. 1996). Although several studies have demonstrated rapid deep-sea benthic response to fresh OM, the quantitative and relative role of the different benthic components in the short-term response remains largely unknown. For example, how does faunal uptake compare to that of the expected key player, Bacteria (Rowe \& Deming 1985, Rowe et al. 1991, Relexans et al. 1996, Turley 2000)? In addition to the tracer recovered in benthic consumers, the algal carbon can also be immediately burnt for energy, with diatom carbon released as ${ }^{13} \mathrm{CO}_{2}$ (Levin et al. 1997); respiration therefore may be an important part of the benthic response. Recent studies have shown that the OM reaching the sediments may be very reactive (e.g. Soetaert et al. 1996, Drazen et al. 1998) and, as in shallow-water environments, deep-sea sediment communities may respond immediately to an input of fresh OM (Graf 1992, Levin et al. 1999).

We examined the role of the major benthic groups in the short-term processing of fresh $\mathrm{OM}$ in the deep sea off NW Spain $\left(42^{\circ} 37.59^{\prime} \mathrm{N}, 10^{\circ} 00.04^{\prime} \mathrm{W}, 2170 \mathrm{~m}\right.$ water depth, bottom-water characteristics: $3.6^{\circ} \mathrm{C}$ and $256 \mu \mathrm{M} \mathrm{O}_{2}$ ). The experiment was conducted on 13 to 16 May 1999 in benthic chambers mounted on a freefalling benthic lander (ALBEX). There was no visible evidence of natural phytodetrital deposits at the time of the experiment, but inputs of fresh material have been documented in the general vicinity (e.g. Pfannkuche 1993, Rice et al. 1994). Axenic ${ }^{13} \mathrm{C}$-enriched Thalassiosira pseudonana, a common diatom in the study area (Estrada 1984), was used as a tracer of labile carbon. Axenic diatoms do not directly mimic the natural OM input to the benthos, but the axenic state is necessary when bacterial assimilation is examined through ${ }^{13} \mathrm{C}$ enrichment of bacterial biomarkers (see 'Materials and methods'). Blair et al. (1996) and Levin et al. $(1997,1999)$ have shown ${ }^{13} \mathrm{C}$-enriched phytodetritus to be a powerful tracer in evaluating the potential of the deep-sea benthos to process labile carbon. Bacterial assimilation of the added carbon was assessed via carbon-isotope analysis of polar lipid-derived fatty acids (PLFAs) specific for Bacteria (Boschker et al. 1998, Middelburg et al. 2000, Moodley et al. 2000), respiration of the added carbon was assessed through ${ }^{13} \mathrm{C}$-enrichment of $\Sigma \mathrm{CO}_{2}$, and uptake by benthic fauna through $\delta^{13} \mathrm{C}_{\text {org }}$ measurements of their body tissue.

\section{MATERIALS AND METHODS}

An axenic clone of the diatom Thalassiosira pseudonana (CCMP 1013, Provasoli-Guillard National Center for Culture of Marine Phytoplankton, Bigelow Laboratory) was cultured in artificial seawater containing $30 \%{ }^{13} \mathrm{C}$-enriched bicarbonate that produced algal carbon consisting of $20.3 \pm 1.8 \%{ }^{13} \mathrm{C}$. Diatoms were concentrated by centrifugation, washed several times to remove the ${ }^{13} \mathrm{C}$-bicarbonate, and freeze-dried. The axenic state of the diatom culture was verified microscopically, by separate PLFA analysis of the freezedried diatoms and by a $0 \mathrm{~h}$ sediment incubation experiment.

A detailed description of the design and working of the ALBEX lander as well as methods of sedimentcommunity oxygen consumption (SCOC) measurements are given in Witbaard et al. (2000). One background SCOC measurement was done during the test deployment of the lander just prior to the uptake experiment. The ${ }^{13} \mathrm{C}$-uptake experiment was conducted during a single deployment, with the lander holding 3 benthic chambers; each chamber measured $12 \times 12 \times 20 \mathrm{~cm}$ and enclosed a water and sediment column of $\sim 10 \mathrm{~cm}$ each: 1 chamber was used for background measurements (ALBEX 1) and the other 2 as experimental chambers (ALBEX 2 and ALBEX 3) which received a pulse of ${ }^{13} \mathrm{C}$-enriched diatoms. Diatoms (23.8 mg corresponding to 6.3 or $434 \mathrm{mg} \mathrm{C}$ $\mathrm{m}^{-2}$ ) were mixed with $0.2 \mu \mathrm{m}$-filtered seawater and placed in a syringe. The syringe was placed upside down (to prevent clogging) and programmed to first extract water in order to re-suspend the diatoms before injection into the chamber. Excess water due to injection of diatom mix was expelled through an exit valve at the opposite end of the lid in order to limit the loss of diatoms during injection. The stirrers were switched on $1 \mathrm{~h}$ after diatom injection and the systems were preset to take water samples for $\mathrm{CO}_{2}$ after 15 and $29 \mathrm{~h}$. A final water sample was taken on deck ( $35 \mathrm{~h}$ after diatom injection). At the end of the experiment, the chambers were processed (within $2 \mathrm{~h}$ ) in a temperature-controlled container $\left(4^{\circ} \mathrm{C}\right)$. Two sub-cores $(3.6 \mathrm{~cm}$ inner diameter) were taken: 1 for PLFA and bulk POC and 1 for meiofauna $>63 \mu \mathrm{m}$. We chose a $63 \mu \mathrm{m}$ sieve in preference to the 38 or $45 \mu \mathrm{m}$ generally used in meiofauna studies in order to facilitate the isolation and hand-picking of the small organisms and a better removal of diatoms possibly attached to the outside of organisms. Three intervals of the remaining sediment $(0-1,1-3$ and $3-5 \mathrm{~cm})$ were sieved on a $300 \mu \mathrm{m}$ sieve for the larger fauna and frozen in glass bottles. Megafauna were not present in our benthic chambers.

In the laboratory, fauna sediment samples were thawed and all organisms handpicked. The large 
fauna (retained on the $300 \mu \mathrm{m}$ sieve) were isolated from different depth intervals but, due to high heterogeneity and low biomass, were combined for measurements. For this fauna, 4 groups were distinguished: (1) metazoan macrofaunal taxa (e.g. polychaetes, bivalves, crustaceans, and sipunculans); (2) metazoan meiofaunal taxa (taxa generally belonging to the meiobenthos, e.g. nematodes, copepods and ostracods); (3) Foraminifera (Protista) that can constitute a major part of the benthos, generally of the meiobenthic size class Foraminifera A (calcareous, agglutinated and soft-shelled); and (4) the group of less 'familiar' large agglutinated deep-sea Foraminifera, Foraminifera B (astrorhizids and komokiaceans: Gooday et al. 1992).

The criterion for living Foraminifera was healthylooking (as opposed to old, fossilised), cytoplasm-filled shells. In cases where this was not easily established, specimens were broken and examined for cytoplasm. However, for komokiacean Foraminifera, the living could not be distinguished from the dead. In the case of large agglutinated astrorhizid Foraminifera, all specimens were broken; some specimens did not contain foraminiferal cytoplasm but were inhabited by polychaetes or isopods that were transferred to the metazoan macrofaunal taxa group. For the group of metazoan macrofaunal taxa and 1 genus of the Foraminifera B group (Rhizammina spp.), samples were first lyophylized and homogenised. For the other faunal groups, whole specimens were combined for measurements. Each sample was then treated with $5 \% \mathrm{HCl}$ in silver boats and the excess acid was removed by drying overnight at $40^{\circ} \mathrm{C}$.

Lipid extraction (from $3 \mathrm{~g}$ of lyophylized sediment per sediment interval) and carbon-isotopic analysis of PLFAs were done according to Boschker et al. (1999) and Middelburg et al. (2000). Details of the measurement of $\delta^{13} \mathrm{C}-\sum \mathrm{CO}_{2}$ and $\delta^{13} \mathrm{C}_{\text {org }}$ of faunal compartments are given in Moodley et al. (2000).

Carbon isotopes are expressed in the delta notation $\left(\delta^{13} \mathrm{C}\right)$ relative to Vienna Pee Dee Belemnite (VPDB): $\delta^{13} \mathrm{C}=\left(\left[{ }^{13} \mathrm{C} /{ }^{12} \mathrm{C}\right]_{\text {sample }} /\left[{ }^{13} \mathrm{C} /{ }^{12} \mathrm{C}\right]_{\text {ref }}-1\right) \times 1000$. Incorporation of ${ }^{13} \mathrm{C}$ is reflected as excess (above background) ${ }^{13} \mathrm{C}$ and is expressed in terms of specific uptake (i.e. $\Delta \delta^{13} \mathrm{C}=\delta^{13} \mathrm{C}_{\text {sample }}-\delta^{13} \mathrm{C}_{\text {background }}$ ) as well as total uptake (I). Specific uptake, as evident in $\Delta \delta^{13} \mathrm{C}\left(\Delta \delta^{13} \mathrm{C}=0\right.$ in the case of no uptake) is a clear indication of uptake of the ${ }^{13} \mathrm{C}$-enriched diatom, but remains a qualitative measure, as it is based on isotope ratio data and is influenced by the amount incorporated, the pool size, and the percentage of ${ }^{13} \mathrm{C}$ in the diatoms (i.e. the intensity of the original labelling). Total uptake is a quantitative measure of ${ }^{13} \mathrm{C}$-uptake and is calculated as the product of excess ${ }^{13} \mathrm{C}(E)$ and biomass of the consumers or concentration of $\mathrm{CO}_{2}$. Excess $(E){ }^{13} \mathrm{C}$ is the dif- ference between the fraction $(F){ }^{13} \mathrm{C}$ of the background ( $\left.F_{\text {background }}\right)$ and the samples $\left(F_{\text {sample }}\right): \mathrm{E}=F_{\text {sample }}-$ $F_{\text {background }}$ where $F={ }^{13} \mathrm{C} /\left({ }^{13} \mathrm{C}+{ }^{12} \mathrm{C}\right)=R /(R+1)$. The carbon isotope ratio $(R)$ was derived from the measured $\delta^{13} \mathrm{C}$ values as: $R=\left(\delta^{13} \mathrm{C} / 1000+1\right) \times R_{\mathrm{VPDB}}$, with $R_{\mathrm{VPDB}}=$ 0.0112372 . For the $F_{\text {background }}$ of $\mathrm{CO}_{2}$, we did not use the $\delta^{13} \mathrm{C}-\sum \mathrm{CO}_{2}$ of the control chamber (average $+1.03 \%$ ) but that determined in a laboratory $35 \mathrm{~h}$ incubation with labelled diatoms using sterile sediment and 0.2 $\mu \mathrm{m}$ filtered seawater, which revealed a constant enrichment in ${ }^{13} \mathrm{CO}_{2}$ equivalent to a $\delta^{13} \mathrm{C}-\Sigma \mathrm{CO}_{2}$ of + $4.44 \%$. This reflects traces of ${ }^{13} \mathrm{C}$-bicarbonate in the added diatoms in spite of extensive rinsing with clean medium during diatom harvesting. The biomass of fauna is generally calculated from weight (wet or dry wt) or from size dimensions converted to carbon content. We calculated the organic carbon content (biomass) of the different faunal groups directly from the area counts given in the standard output of the isotope ratio mass spectrometer calibrated with sucrose (0 to $\left.84 \mu \mathrm{gC}, \mathrm{r}^{2}=0.98\right)$. This method overcomes the need for separate biomass estimation or measurements and offers a direct and accurate calculation of carbon uptake and biomass in the same measurement. Bacterial data are based on the concentrations and ${ }^{13} \mathrm{C}$ content of Bacteria-specific biomarkers (14:0 iso, 15:0 iso, 15:0 anteiso, 16:0 iso) assuming that bacterial biomarkers $=14 \%$ of total bacterial PLFAs (calculated from Rajendran et al. 1993, 1994, Guezennec \& Fialamedioni 1996, Steward et al. 1996, Boschker et al. 1998)

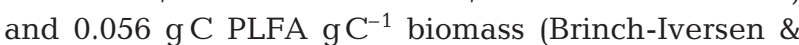
King 1990), as described in Middelburg et al. (2000). Finally, the uptake of total added algal carbon $\left({ }^{12} \mathrm{C}+\right.$ ${ }^{13} \mathrm{C}$ ) was calculated as the quotient of total uptake $(I)$ and the fractional abundance of ${ }^{13} \mathrm{C}$ in the algae (0.203). All error terms presented in the text are standard errors.

\section{RESULTS AND DISCUSSION}

Approximately $229 \pm 74 \mathrm{mg} \mathrm{C} \mathrm{m}^{-2}$ of labelled diatom carbon was recovered in the upper $5 \mathrm{~cm}$ of the sediment column as bulk POC (calculated from the excess $\mathrm{PO}^{13} \mathrm{C}$ and POC content) indicating that $\sim 40 \%$ of the diatoms was lost during deployment or injection. The amount of recovered diatom carbon represented $0.7 \pm 0.1 \%$ of the natural particulate organic carbon in the 0 to $1 \mathrm{~cm}$ interval of the sediment $\left(33.5 \pm 5.4 \mathrm{~g} \mathrm{C} \mathrm{m}^{-2}\right)$.

Background sediment community oxygen consumption measured during the test deployment $(0.53 \mathrm{mmol}$ $\mathrm{O}_{2} \mathrm{~m}^{-2} \mathrm{~d}^{-1}$ ) was similar to that measured in the control (ALBEX 1) benthic chamber $\left(0.48 \mathrm{mmolO}_{2} \mathrm{~m}^{-2} \mathrm{~d}^{-1}\right.$ : Table 1). The SCOC measured in the experimental chambers was, on average, twice that of the back- 
Table 1. Weighted average $\delta^{13} \mathrm{C}$ signatures (\%), biomass and carbon uptake $\left(\mathrm{mgC} \mathrm{m} \mathrm{m}^{-2}\right)$ of different benthic components in the control benthic chamber (ALBEX 1) and 2 experimental benthic chambers (ALBEX 2 and ALBEX 3). Values are for 0 to $5 \mathrm{~cm}$ sediment depth, except for meiofauna $>63 \mu \mathrm{m}(0$ to $1 \mathrm{~cm}$ interval). SCOC: sediment-community oxygen consumption; PLFAs: polar lipidderived fatty acids

\begin{tabular}{|c|c|c|c|}
\hline Parameter & ALBEX 1 & ALBEX 2 & ALBEX 3 \\
\hline $\operatorname{SCOC}\left(\mathrm{mmolO}_{2} \mathrm{~m}^{-2} \mathrm{~d}^{-1}\right)$ & 0.48 & 0.74 & 1.37 \\
\hline $\begin{array}{l}\text { Respiration of added carbon }{ }^{a} \\
\left(\mathrm{mgC} \mathrm{m}^{-2} 35 \mathrm{~h}^{-1}\right)\end{array}$ & - & 2.47 & 3.31 \\
\hline \multicolumn{4}{|l|}{$\delta^{13} \mathrm{C}$} \\
\hline Bacterial biomarkers ${ }^{\mathrm{b}}$ & -24.4 & -11.5 & -13.9 \\
\hline Foraminifera $\mathrm{A}^{\mathrm{c}}$ & -21.4 & +2.952 & +3.993 \\
\hline Foraminifera $\mathrm{B}^{\mathrm{d}}$ & -22.1 & +518 & +100 \\
\hline Metazoan meiofauna $^{\mathrm{e}}$ & -19.0 & -12.63 & -8.6 \\
\hline Macrofauna $^{\mathrm{f}}$ & -20.5 & +121 & +53.5 \\
\hline Meiofauna $>63 \mu \mathrm{m}^{g}$ & -19.7 & Lost & +3.254 \\
\hline \multicolumn{4}{|l|}{ Biomass (C uptake) } \\
\hline Bacteria & 1.360 & $1.700(1.21)$ & $1.570(1.53)$ \\
\hline Foraminifera $\mathrm{A}^{\mathrm{c}}$ & 9.9 & $8.2(1.29)$ & $8.4(1.74)$ \\
\hline Foraminifera $\mathrm{B}^{\mathrm{d}}$ & 9.4 & $13.9(0.49)$ & $15.9(0.11)$ \\
\hline Metazoan meiofauna ${ }^{\mathrm{e}}$ & 5.2 & $7.6(<0.01)$ & $6.4(<0.01)$ \\
\hline Macrofauna $^{\mathrm{f}}$ & 44.1 & $35.8(0.27)$ & $39.1(0.16)$ \\
\hline Meiofauna $>63 \mu \mathrm{m}^{g}$ & 11.8 & Lost & $22.5(3.84)$ \\
\hline \multicolumn{4}{|c|}{$\begin{array}{l}\text { a Based on excess }{ }^{13} \mathrm{CO}_{2} \text { and } \mathrm{CO}_{2} \text { concentration at the end of the incubation } \\
\text { b Depth average of PLFAs 14:0 iso, 15:0 iso, 15:0 anteiso and 16:0 iso } \\
\text { 'Group of 'familiar' Foraminifera } \\
\text { dGoup of less 'familiar' large agglutinated Foraminifera } \\
\text { e'Metazoan meiofaunal taxa } \\
\text { e } \\
\text { fBulk measurement of macrofaunal taxa retained on } 300 \mu \mathrm{m} \text { sieve } \\
\text { 9Metazoan meiofaunal taxa plus Foraminifera but excluding group of less } \\
\text { 'familiar' large agglutinated Foraminifera }\end{array}$} \\
\hline
\end{tabular}

ground value (Table 1), but because of limited replication this difference has low significance. However, independent of significant changes in SCOC, ${ }^{13} \mathrm{C}$ enrichment in $\Sigma \mathrm{CO}_{2}$ is a sensitive tool for detecting respiration of the pre-labelled added carbon (see also Blair et al. 1996). In our in situ experiment, a rapid benthic response was recorded in the respiration of the added

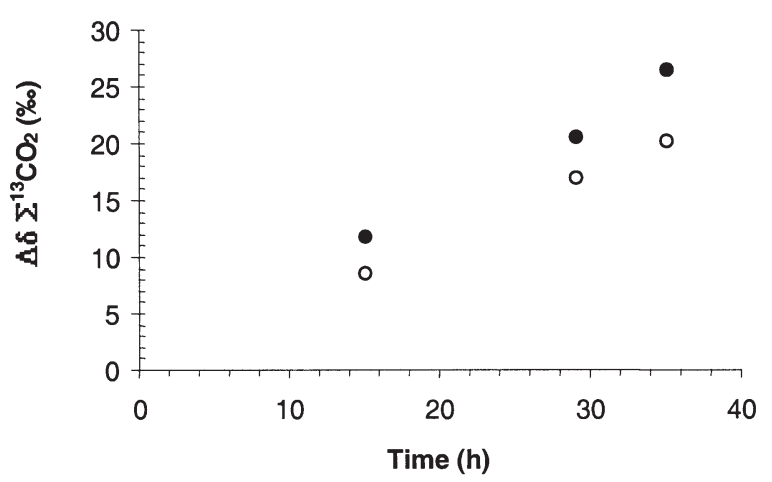

Fig. $1 .{ }^{13} \mathrm{C}$-enrichment of total inorganic carbon $\left(\Delta \delta \Sigma^{13} \mathrm{CO}_{2}\right)$ versus time. Values from experimental chambers, ALBEX 2 (०) and ALBEX $3(\bullet)$ carbon, as reflected in a linear increase in excess ${ }^{13} \mathrm{CO}_{2}$ during the time period measured (Fig. 1). Quantitatively, within $35 \mathrm{~h}, 6.3 \pm 0.6 \mathrm{mg} \mathrm{m}^{-2}$ of the added carbon was processed by the benthic compartments examined, i.e. Bacteria in the upper $5 \mathrm{~cm}$, fauna of the upper 5 $\mathrm{cm}$ retained on a $300 \mu \mathrm{m}$ sieve, and total community respiration. The role of the smaller fauna (meiobenthos retained on a $63 \mu \mathrm{m}$ sieve) will be discussed separately because 1 replicate (ALBEX 2) was lost during processing. The major signal of benthic processing was recorded as $\mathrm{CO}_{2}(45.6 \pm 2.6 \%)$.

Respiration of the added carbon represented $16.4 \pm 2.6 \%$ of total respiration (calculated from sediment oxygen consumption using a respiratory quotient of 1 ; Table 1). This supports previous evidence that benthic processing of labile carbon may be rapid in deep-sea sediments under well-oxygenated conditions (e.g. Graf 1992, Blair et al. 1996, Levin et al. 1997, 1999). Bacterial assimilation accounted for $21.7 \pm 0.6 \%$ of the processed carbon. Among the fauna retained on a $300 \mu \mathrm{m}$ sieve, metazoan meiofaunal taxa took up $<0.1 \%$, metazoan macrofaunal taxa ingested $3.5 \pm 1.2 \%$, and $29.1 \pm 2.0 \%$ of the processed carbon was recovered in Foraminifera (Table 1). The ultimate long-term fate of OM escaping burial is respiration to $\mathrm{CO}_{2}$ (e.g. Rowe et al. 1991). It is evident that respiration may be a primary sink of labile OM also in the very short term (hours to days). Similarly, in shallow marine environments, $\mathrm{CO}_{2}$ was found to be a major sink of organic matter (e.g. Olafsson et al. 1999, Moodley et al. 2000). A transient fate of OM reaching the seafloor is benthic biomass, which in the deep sea is primarily dominated by Bacteria (Rowe \& Deming 1985, Rowe et al. 1991, Relexans et al. 1996, Turley 2000). Bacteria account for $>95 \%$ of the biomass standing stock at our study site (Table 1), and accordingly Bacteria are key players in processing the added carbon (Fig. 2). It is important to note that incorporation of phytodetritus-derived ${ }^{13} \mathrm{C}$ in bacterial PLFA represents assimilation only; another part of bacterial uptake has been respired and is probably the main contributor to total community respiration (Table 1).

Among the fauna, a surprisingly large fraction of the processed carbon was recovered in Foraminifera (Fig. 2). The highest ${ }^{13} \mathrm{C}$-enrichment was also found in Foraminifera (Table 1). With uptake experiments, there is always the possibility of artefacts due to adhesion of 
the added algal material onto the exterior of organisms (Levin et al. 1999). However, a 6 h on-deck incubation revealed limited ${ }^{13} \mathrm{C}$-enrichment in both the group of 'familiar' Foraminifera as well as the group of large agglutinated Foraminifera (average $\Delta \delta^{13} \mathrm{C}+15.4 \%$ ) compared to an average $\Delta \delta^{13} \mathrm{C}$ of +3494 and $+331 \%$ respectively for the 2 groups after $35 \mathrm{~h}$ in situ. This large difference clearly indicates that the high ${ }^{13} \mathrm{C}$-enrichment recorded in the Foraminifera after $35 \mathrm{~h}$ in situ is not an artefact of adhesion but reflects active uptake. Additionally, for a group of Foraminifera in which maximum adhesion may be expected (Rhizammina spp., due their coarse agglutinated branching shells), ${ }^{13} \mathrm{C}$ enrichment was very limited (an average $\Delta \delta^{13} \mathrm{C}$ of $+12.3 \%$ ). This demonstrates that our sieving and cleaning procedures were efficient. Additionally, other studies have also demonstrated that benthic organisms, including Foraminifera, do indeed ingest and assimilate labelled diatoms very rapidly (e.g. Blair et al. 1996, Levin et al. 1997, 1999, Herman et al. 2000, Middelburg et al. 2000, Moodley et al. 2000). Foraminiferal ingestion of algae under high pressure and low temperature has also been documented (Turley et al. 1993).

The total biomass of Foraminifera is negligible compared to that of Bacteria (Table 1), but uptake of added carbon is more in the range of Bacteria than other faunal groups. Apart from a possible preference against fresh OM, the differential short-term uptake among the faunal groups (Fig. 2) reflects primarily their efficiency in acquiring food particles. Foraminifera possess granuloreticulate pseudopodia that can form long, extensive networks (Travis \& Bowser 1991) that constitute an efficient system for trapping, gathering and accumulating food particles (Bowser et al. 1992, Gooday et al. 1996; present authors, pers. obs.). Foraminifera are evidently important consumers of fresh organic matter but their relatively low biomass suggests that they are probably more dependent on fresh material, presumably of limited input, than are Bacteria. Additionally, Foraminifera may be important links in the benthic food chain in the deep sea. In 1 of the experimental chambers, the gut of a scaphopod was found packed with calcareous Foraminifera, and there are numerous reports of predation on Foraminifera by a wide variety of organisms (e.g. Ahrens et al. 1997, Gudmundsson et al. 2000), including scaphopods (Davies 1987 in Gooday et al. 1992). The high ${ }^{13} \mathrm{C}$ enrichment found in Foraminifera, especially in the 'familiar' group (average $\Delta \delta^{13} \mathrm{C}+3,421 \%$ ), suggests that they are important packaging agents of fresh OM, and that subsequent predation results in efficient trophic transfer. In contrast, Bacteria had relatively low ${ }^{13} \mathrm{C}$-enrichment (average $\Delta \delta^{13} \mathrm{C}+11.7 \%$ ), indicating either that the bacterial community is slow-growing or that only a fraction of the bacterial community is in- volved in the short-term response. However, as noted above, a major part of community respiration may be attributable to bacterial processing of the added carbon. On the basis of bacterial assimilation $(A)$ and total community respiration $(R)$, bacterial assimilation efficiency $(A /[A+R])$ is $>0.32$, consistent with values reported for oxic shallow marine and lake environments (del Giorgio \& Cole 1998) as well as for other deep-sea sediment bacterial assemblages (Boetius et al. 2000).

Among the fauna retained on a $300 \mu \mathrm{m}$ sieve, the uptake by the macrofaunal taxa was relatively low and that of metazoan meiofaunal taxa was extremely limited (Fig. 2). However, the role of meiofauna is by definition underestimated when using a $300 \mu \mathrm{m}$ sieve. We examined surface sediments (0 to $1 \mathrm{~cm}$ ) using a sieve with a smaller mesh size (63 $\mu \mathrm{m})$ excluding the group of large agglutinated Foraminifera. The meiofauna assemblage retained on the $63 \mu \mathrm{m}$ sieve consisted primarily of Foraminifera and a strong enrichment in ${ }^{13} \mathrm{C}_{\text {org }}$ was evident (Table 1). The numbers of nematodes may have been larger if a finer sieve had been used, but this is not expected to have major consequences for biomass or uptake trends. Other studies have recorded limited short-term uptake of diatoms by nematodes (Levin et al. 1999, Olafsson et al. 1999, Middelburg et al. 2000). It is unfortunate that the number of metazoan meiofauna was too low to measure separately. When the uptake in the smaller size fraction is taken into account, then the amount of added carbon processed in ALBEX 3 (the meiobenthos sample of ALBEX 2 was lost during processing) increases from 6.9 to $9.0 \mathrm{mg}$, with $36.9 \%$ recovered as $\mathrm{CO}_{2}, 17.1 \%$ assimilated by Bacteria, $42.9 \%$ taken up by the meiofauna retained on a $63 \mu \mathrm{m}$ sieve (primarily Foraminifera), $1.7 \%$ ingested by the macrofauna and $1.2 \%$ taken up by the group of less 'familiar' large agglutinated Foraminifera retained on a $300 \mu \mathrm{m}$ sieve. Bacteria (assimilation and respiration) and Fora-

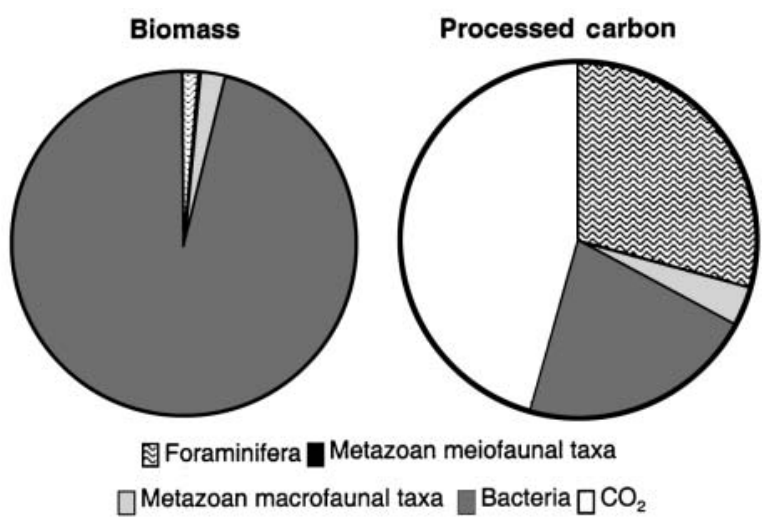

Fig. 2. Proportional division of biomass and processed carbon among the different benthic compartments. Fauna are those retained on a $300 \mu \mathrm{m}$ sieve and values are average of the 2 experimental chambers 
minifera were evidently the key players in this shortterm benthic response to an input of fresh material. This indicates that small-sized organisms, in particular Bacteria, play a dominant role in carbon-processing (Pfannkuche 1993). Although Foraminifera were clearly important competitors of Bacteria at this deep-sea site, other faunal groups may out-compete Foraminifera under different environmental settings. In a continental slope setting (850 $\mathrm{m}$ depth) supporting a rich benthic community, some species of deposit-feeding polychaetes exhibited relatively strong ${ }^{13} \mathrm{C}$-enrichment, indicating rapid ingestion of algal carbon, but at a relatively organic carbon-poor site, phytodetritus uptake by large agglutinated Foraminifera was more pronounced (Levin et al. 1999). Earlier studies have also highlighted that Foraminifera may be rapid and important consumers of phytodetritus (Meyer-Reil \& Koster 1991, Altenbach 1992, Gooday et al. 1992, 1996, Pfannkuche 1993, Graf \& Linke 1992, Linke et al. 1995, Drazen et al. 1998). How this quantitatively compares to bacterial assimilation and uptake by other faunal groups in the different environmental settings remains to be established. Although this study demonstrates quantitatively that Foraminifera play an important role in benthic carbon cycling, their relative role can be influenced by several factors: e.g. the history and quality of the food supply and the size (and structure) of the benthic community. The high dominance of bacterial biomass suggests that Bacteria dominate long-term carbon mineralisation and are probably, in contrast to faunal components, less dependent on highly reactive carbon. Specific studies are required to elucidate whether Bacteria are sinks or links of organic carbon.

The ability of the deep-sea benthic community to respond rapidly is clear from the processing of 6 to $9 \mathrm{mg} \mathrm{C} \mathrm{m}{ }^{-2}$ within $35 \mathrm{~h}$. This, however, still represents a small fraction of the available carbon. Even if we double the total faunal uptake to take into account other protists (e.g. flagellates and ciliates) and smaller meiofauna in the deeper layers, a maximum of $\sim 13 \mathrm{mg}$ $(6 \%)$ of the added carbon would have been processed. In contrast, in a vastly different marine environment, for an intertidal sediment community incubated at $16^{\circ} \mathrm{C}$, respiration alone accounted for the processing of $\sim 61 \mathrm{mg}(12 \%)$ of the added diatom carbon within $35 \mathrm{~h}$ (authors' unpubl. data). This suggests that the prevailing deep-sea conditions of low temperatures in combination with low biomass concentrations and composition limits and slows down the recycling of organic matter, at least in the short term.

Acknowledgements. Technical assistance by Ko Verschuure, Pieter van Rijswijk, Joop Nieuwenhuize, Ute Wollenzien, Henk Franken and Eilke Berghuis is greatly appreciated. The captain and crew of the RV 'Pelagia' are thanked for their pleasant and professional services. Lisa Levin, the contributing editor, and 3 anonymous reviewers provided helpful comments on this manuscript. This research was supported by the Netherlands Organization for Scientific Research, Earth and Life Sciences (NWO-ALW). This is publication number 2914 of the NIOO-KNAW, Yerseke, The Netherlands.

\section{LITERATURE CITED}

Ahrens MJ, Graf G, Altenbach AV (1997) Spatial and temporal distribution patterns of benthic Foraminifera in the Northeast Water Polynya, Greenland. J Mar Syst 10: $445-465$

Altenbach AV (1992) Short-term processes and patterns in the foraminiferal response to organic flux rates. Mar Micropaleontol 19:119-129

Billett DSM, Lampitt RS, Mantoura RFC (1983) Seasonal sedimentation of phytoplankton to the deep-sea benthos. Nature 302:520-522

Blair NE, Levin LA, DeMaster DJ, Plaia G (1996) The shortterm fate of fresh algal carbon in continental slope sediments. Limnol Oceanogr 41:1208-1219

Boetius A, Lochte K (1996) Effect of organic enrichment on hydrolytic potentials and growth of bacteria in deep-sea sediments. Mar Ecol Prog Ser 140:239-250

Boetius A, Ferdelman T, Lochte K (2000) Bacterial activity in sediments of the deep Arabian Sea in relation to vertical flux. Deep-Sea Res Part II 47:2835-2875

Boschker HTS, Nold SC, Wellsbury P, Bos D, de Graaf W, Pel R, Parkes RJ, Cappenberg TE (1998) Direct linking of microbial populations to specific biogeochemical processes by ${ }^{13} \mathrm{C}$-labelling of biomarkers. Nature 392:801-805

Boschker HTS, de Brouwer JFC, Cappenberg TE (1999) The contribution of macrophyte derived organic matter in microbial biomass in salt marsh sediments: stable carbonisotope analysis of microbial biomarkers. Limnol Oceanogr 44:309-319

Bowser SS, Alexander SP, Stockton WL, DeLaca TE (1992) Extracellular matrix auguments mechanical properties of pseudopodia in the carnivorous foraminiferan Astrammina rara: role in prey capture. J Protozool 39:724-732

Brinch-Iversen J, King GM (1990) Effects of substrate concentration, growth rate, and oxygen availability on relationships among bacterial carbon, nitrogen and phospholipid phosphorus content. FEMS Microbiol Ecol 74:345-356

Cahet G, Sibuet M (1986) Activité biologique en domain profond: transformations biochimiques in situ de composés organiques marqués au carbone-14 à l'interface eausedimént par $2000 \mathrm{~m}$ de profondeur dans le Golfe de Gascogne. Mar Biol 90:307-315

Cahet G, Daumas R, Sibuet M (1990) In situ experimentation at the water/sediment interface in the deep sea. 2. Biotransformation of dissolved organic substrates by the microbial communities at $2000 \mathrm{~m}$ depth in the Bay of Biscay. Prog Oceanogr 24:169-178

del Giorgio PA, Cole JJ (1998) Bacterial growth efficiency in natural aquatic systems. Annu Rev Ecol Syst 29:503-541

Drazen JC, Baldwin RJ, Smith KL Jr (1998) Sediment community response to a varying food supply at an abyssal station in the NE Pacific. Deep-Sea Res Part II 45:893-913

Estrada M (1984) Phytoplankton distribution and composition off the coast of Galicia (northwest of Spain). J Plankton Res 6:417-434

Gooday AJ, Turley CM (1990) Responses of benthic organisms to inputs of organic material to the ocean floor. Phil Trans R Soc Lond A Math Phys Sci 331:119-138 
Gooday AJ, Levin LA, Linke P, Heeger T (1992) The role of benthic Foraminifera in deep-sea food webs and carbon cycle. In: Rowe GT, Pariente V (eds) Deep-sea food chains and global carbon cycle. Kluwer Academic Publishers, Dordrecht, p 63-91

Gooday AJ, Pfannkuche O, Lambshead PJD (1996) Apparent lack of response by metazoan meiofauna to phytodetritus deposition in the bathyal north-eastern Atlantic. J Mar Biol Assoc UK 76:297-310

Graf G (1989) Benthic-pelagic coupling in a deep-sea benthic community. Nature 341:437-439

Graf G (1992) Benthic-pelagic coupling: a benthic view. Oceanogr Mar Biol Annu Rev 30:149-190

Graf G, Linke P (1992) Adenosine nucleotides as indicators of deep-sea benthic metabolism. In: Rowe GT, Pariente V (eds) Deep-sea food chains and global carbon cycle. Kluwer Academic Publishers, Dordrecht, p 237-243

Gudmundsson G, von Schmalensee M, Svavarsson J (2000) Are foraminifers (Protozoa) important food for small isopods (Crustacea) in the deep sea? Deep-Sea Res Part I 47: Oceanogr Res Pap 2093-2109

Guezennec J, Fialamedioni A (1996) Bacterial abundance and diversity in the Barbados trench determined by phospholipid analysis. FEMS Microbiol Ecol 19:83-93

Herman PMJ, Middelburg JJ, Widdows J, Lucas CH, Heip CHR (2000) Stable isotopes as trophic tracers: combining field sampling and manipulative labelling of food resources for macrobenthos. Mar Ecol Prog Ser 204:93-100

Levin LA, Blair NE, DeMaster DJ, Plaia G, Fornes W, Martin C, Thomas C (1997) Rapid subduction of organic matter by maldanid polychaetes on the North Carolina Slope. J Mar Res 55:595-611

Levin LA, Blair NE, Martin CM, DeMaster DJ, Plaia G, Thomas CJ (1999) Macrofaunal processing of phytodetritus at two contrasting sites on the Carolina margin: in situ experiments using ${ }^{13} \mathrm{C}$-labeled diatoms. Mar Ecol Prog Ser $182: 37-54$

Linke P (1992) Metabolic adaptations of deep-sea benthic Foraminifera to seasonally varying food input. Mar Ecol Prog Ser 81:51-63

Linke P, Altenbach AV, Graf G, Heeger T (1995) Responses of deep-sea benthic Foraminifera to a simulated sedimentation event. J Foraminifer Res 25:75-82

Meyer-Reil LA, Köster M (1991) Fine scale distribution of hydrolytic activity associated with foraminiferans and Bacteria in deep-sea sediments of the Norwegian Greenland Sea. Kiel Meeresforsch (Sonderh)8:121-126

Middelburg JJ, Barranguet C, Boschker HTS, Herman PMJ, Moens T, Heip CHR (2000) The fate of intertidal microphytobenthos carbon: an in situ ${ }^{13} \mathrm{C}$-labelling study. Limnol Oceanogr 45:1224-1234

Moodley L, Boschker HTS, Middelburg JJ, Pel R, Herman PMJ, de Deckere E, Heip CHR (2000) Ecological significance of benthic Foraminifera: ${ }^{13} \mathrm{C}$ labelling experiments. Mar Ecol Prog Ser 202:289-295

Olafsson E, Modig H, van de Bund WJ (1999) Species specific uptake of radio-labelled phytodetritus by benthic meiofauna from the Baltic Sea. Mar Ecol Prog Ser 177:63-72

Pfannkuche O (1993) Benthic response to the sedimentation of particulate organic matter at the BIOTRANS station, $47^{\circ} \mathrm{N}-20^{\circ} \mathrm{W}$. Deep-Sea Res Part II 40:135-150

Pfannkuche O, Boetius A, Lochte K, Lundgreen U, Thiel H (1999) Responses of deep-sea benthos to sedimentation patterns in the north-east Atlantic in 1992. Deep-Sea Res Part I 46:573-596

Editorial responsibility: Lisa Levin (Contributing Editor), La Jolla, California, USA
Rajendran N, Suwa Y, Urushigawa Y, Simidu U (1993) Distribution of phospholipid ester-linked fatty acid biomarkers for bacteria in the sediments of Ise Bay, Japan. Mar Chem 42:39-56

Rajendran N, Matsuda O, Urushigawa Y, Simidu U (1994) Characterization of microbial community structure in the surface sediment of Osaka Bay, Japan, by phospholipid fatty acid analysis. App Environ Microbiol 60:248-257

Relexans JC, Deming J, Dinet A, Gaillard JF, Sibuet M (1996) Sedimentary organic matter and micro-meiobenthos with relation to the trophic conditions in the tropical northeast Atlantic. Deep-Sea Res Part I 43:1343-1368

Rice AL, Thurston MH, Bett BJ (1994) The IOSDL deepseas programme: introduction and photographic evidence for the presence and absence of a seasonal input of phytodetritus at contrasting abyssal sites in the north-eastern Atlantic. Deep-Sea Res Part I 41:1305-1320

Rowe GT, Deming JW (1985) The role of bacteria in the turnover of organic carbon in deep-sea sediments. J Mar Res 43:925-950

Rowe G, Sibuet M, Deming J, Khripounoff A, Tietjen J, Macko S, Theroux R (1991) 'Total' sediment biomass and preliminary estimates of organic carbon residence time in deep-sea benthos. Mar Ecol Prog Ser 79:99-114

Sayles FL, Martin WR, Deuser WG (1994) Responses of benthic oxygen demand to particulate organic carbon supply in the deep sea near Bermuda. Nature 371:686-689

Smith KL Jr, Baldwin RJ (1984) Seasonal fluctuations in deepsea sediment community oxygen consumption: central and eastern North Pacific. Nature 307:624-626

Smith KL Jr, Kaufmann RS (1999) Long-term discrepancy between food supply and demand in the deep eastern North Pacific. Science 284:1174-1177

Soetaert K, Herman PMJ, Middelburg JJ (1996) Dynamic response of deep-sea sediments to seasonal variations: a model. Limnol Oceanogr 41:1651-1668

Steward CC, Nold SC, Ringelberg DB, White DC, Lovell CR (1996) Microbial biomass and community structures in the burrows of bromophenol producing and non-producing marine worms and surrounding sediments. Mar Ecol Prog Ser 133:149-165

Thiel H, Pfannkuche O, Scriever G, Lochte K and 6 others (1989) Phytodetritus on the deep-sea floor in a central oceanic region of the northeast Atlantic. Biol Oceanogr 6: 203-239

Travis JL, Bowser SS (1991) The motility of Foraminifera. In: Lee JJ, Anderson OR (eds) Biology of Foraminifera. Academic Press, London, p 91-155

Turley C (2000) Bacteria in the cold deep-sea benthic boundary layer and sediment-water interface of the NE Atlantic. FEMS Microbiol Ecol 33:89-99

Turley CM, Lochte K (1990) Microbial response to the input of fresh detritus to the deep-sea bed. Palaeogeogr Palaeoclimatol Palaeoecol 89:3-23

Turley CM, Gooday AJ, Green JC (1993) Maintenance of abyssal benthic Foraminifera under high pressure and low temperature: some preliminary results. Deep-Sea Res Part I 40:643-652

Witbaard R, Duineveld GA, van der Weele JA, Berghuis EM, Reyss JP (2000) The benthic response to seasonal deposition of phytopigments at the Porcupine Abyssal Plain in the north-east Atlantic. J Sea Res 43:15-31

Witte U, Pfannkuche O (2000) High rates of benthic carbon remineralisation in the abyssal Arabian Sea. Deep-Sea Res Part II 47:2785-2804

Submitted: July 27, 2001; Accepted: December 20, 2001

Proofs received from author(s): May 17, 2002 